\title{
Open Access pályázati rendszer technikai megvalósítása és a szerzők támogatása a Szegedi Tudományegyetemen
}

\author{
Muzs Krisztina \\ SZTE Klebelsberg Könyvtár \\ krisztina.muzs@ek.szte.hu \\ Molnár Tamás \\ SZTE Klebelsberg Könyvtár \\ tamas.molnar@ek.szte.hu \\ Hoczopán Szabolcs \\ SZTE Klebelsberg Könyvtár \\ szabolcs.hoczopan@ek.szte.hu
}

\begin{abstract}
A Szegedi Tudományegyetem Open Access stratégiájának meghatározó része a támogatás nyújtása a szerzők nyiltt hozzáférésü publikációinak közlési dijának fedezéséhez, a megfelelő folyóirat kiválasztásához illetve a szerzői támogatás biztositása. Egy Szegedi Tudományegyetem méretü intézményben a saját büdzséböl fizetett, vagy konzorcionális forrásból fedezett publikációs költségek, illetve az eleve nyilt hozzáférésünek szánt cikkeken felül, a rendelkezésünkre álló, egyre növekvő számú, opcionális (Read and Publish) Open Access közlési lehetőség adminisztrációja komoly kihívás a munkafolyamatba bevont kollégák számára. Nemcsak a ténylegesen elfogadott közlemények igénylik kollégáink figyelmét, de a készülőben és az utánkövetés alatt lévők is, szigorú összhangban az intézményi Open Access támogatási szabályzattal.

A szerteágazó feladatok ellátásához szükségünk volt egy online adminisztrációs rendszere, mely számos automatizmussal könnyiti meg kollégáink munkáját, és minden számunkra fontos funkciót egy felületen tesz elérhetővé a támogatási döntéshozatal elökészitésétöl kezdve a pénzügyi adminisztráción keresztül a publikációk utánkövetéséig. A rendszer szükségszerüen összehangolva müködik az egyes kiadók saját online Open Access adminisztrációs felületével, máskülönben nagyon hamar elvesznénk az adatok tengerében. Az adminisztrációs rendszer része a Szegedi Tudományegyetem publikálás támogató felületének, a Szerzői Eszköztárnak.
\end{abstract}

The main part of the University of Szeged Open Access strategy is the provision of support for the payment of APCs, the selection of the appropriate journal and the author support. In an institution like the University of Szeged, where publishing costs are paid from several budgets or covered by many consortium contracts, and in addition the Open Access born articles, the administration of the increasing number of optional Open Access possibilities is a serious challenge for the colleagues involved in the workflow. Of course not only the accepted publications requiring the attention of our colleagues, but also the under preparation articles and the follow-ups, in strict accordance with the institutional Open Access policy. 
In order to perform diverse tasks, we needed an administrative system that facilitates the work of our colleagues with a number of automations and provide every important function for us, from the preparation of decision making through financial administration to the follow-up. The system will necessarily work with each publisher's own Open Access administration interface, otherwise we would be lost in the sea of data very soon. The administration system is part of the so-called Author's Toolbox, which provide more and more author support services for the University of Szeged.

Keywords: open access, Article Processing Charge, Read and Publish, institutional author support

\section{A szerzök támogatása}

Az SZTE Klebelsberg Könyvtár 2015-ben kezdte meg a Szerzői Eszköztár ${ }^{1}$ projekt keretében az egyetem szerzőinek publikációs támogatását. A Szerzői Eszköztár valójában egy folyamatosan bövülő "szolgáltatás csokor" melyben az egyetem szerzőit kivánjuk segiteni a publikációs folyamat során felmerülő problémák megoldásában. Természetesen senki helyett nem írjuk meg a cikkét, de segitséget nyújtunk a folyóirat kiválasztásban, publikációs workshopok szervezésében, az előzetes lektorálásban, plágiumellenörzésben, a publikációs költség fedezésében, a repozitálásban, az MTMT feltöltésben és a szerző jogi kérdésekben².

Az utóbbi időben a szerzőket támogató szolgáltatásaink mellett elinditottuk a szerkesztőségeket támogató szolgáltatásainkat, melynek keretében Open Journal System alapú folyóirat platformot, és technikai támogatást biztositunk az egyetemi folyóiratok számára, hogy szabályos Open Access folyóiratként jelenhessenek meg. A platformon futó folyóiratok esetében a megszülető cikkeket digitális objektum azonositóval, és ezzel plágiumvédelemmel látjuk el. A szerkesztőségek kérésére a folyóiratplatformunkat összekötöttük a CrossCheck plágiumellenörző rendszerrel is, így akár minden a szerzők által beküldött cikk, automatikusan plágiumellenörzésen is áteshet. Az esetlegesen felmerülő szerzői jogi ügyletek rendezésére az egyetem a Copyright Clearence Centerrel áll kapcsolatban, hogy az esetlegesen az egyetem szerzői által benyújtott cikkekben szereplő külső forrásból felhasznált ábrákra, szövegrészekre stb. gördülékenyen tudjunk újrafelhasználási engedélyeket szerezni.

Magának a publikációs támogatási programnak a következő alapvető céljai vannak: segiteni a szerzőket a nyilt publikációk megjelentetésében, az ügyintézés gyorsitása, az SZTE láthatóságának növelése, a nemzetközi rangsorokban való

\footnotetext{
1 Keveházi Katalin. Nyilt hozzáférés a gyakorlatban. Tudományos és Mûszaki Tájékoztatás 63 5. sz. (2016.), 193-197.

2 Dr. Meskó Eszter. Kutatást támogató könyvtár, a tartalomszolgáltatástól a tartalomgazdaságig. Networkshop 2016 konferencia, Tartalomszolgáltatások https://kifu.videotorium.hu/hu/recordings/12958/kutatast-tamogato-konyvtar-atartalomszolgaltatastol-a-tartalom-gazdasagig 
Muzs Kriszina - Molnár Tamás - Hoczopán Szabolcs: Open Access pályázati rendszer technikai megvalósitása és a szerzők támogatása a Szegedi Tudományegyetemen

elörelépés elősegítése, az MTMT feltöltöttségének javítása és általánosságban az Open Access ügyének támogatása.

Az utóbbi években azt tapasztaltuk, hogy az Open Access publikációk körüli adminisztráció legalább annyira munkaigényes, mint az elöfizetések intézése. Az egyetlen szervként, ami intézményi szinten vállalja fel a nyillt hozzáférés adminisztrációját, a kiadók számára a Szegedi Tudományegyetem Klebelsberg Kuno Könyvtára vált az elsődleges kapcsolattartóvá, így azok az esetek többségében nem csak azokkal a beküldött cikkekkel keresnek meg minket, melyek szigorúan véve a támogatási körünkbe tartoznak, hanem minden egyetemi publikációval kapcsolatban. Tulajdonképpen annak köszönhetően, hogy a tagsági szerződéseket könyvtárként kötöttük meg a kiadókkal, rálátást nyertünk majdnem minden, az egyetemen megszülető Open Access, vagy potenciálisan azzá alakitható publikációra.

\section{Open Access támogatási feltételek}

A fentiekböl következöen az elsődleges feladatunk, hogy még a kiadói rendszerben megfelelö irányba inditsuk el a cikkek ügyintézését: a központilag támogatott publikációkat a könyvtár kiadói adminisztrációs rendszerben kialakitott munkaterülete felé, a többit pedig a szerzők felé irányitva. Ahhoz, hogy pontosan tudjuk, melyik feltöltéssel mi a teendönk, szükségünk volt egy átfogó egyetemi Open Access adminisztrációs rendszerre, amely már elözetesen minden adatot tartalmaz a gyors döntéshozatalhoz.

Az egyetemi Open Access támogatást az intézmény olyan feltételekhez kötötte, melyek mind a szerzőknek, mind az egyetemnek hasznosak. A feltételek ugyan folyamatosan változnak, követve az új lehetöségeket, igényeket és kihivásokat, de alapvetően az alábbi pontokkal kezdtük meg a munkát: a folyóiratnak tiszta Open Accessnek és Q1-Q2 besorolásúnak kell lennie. A levelezö szerzőnek SZTE-s affiliácójúnak kell lennie, a cikket SZTE-es email címmel kell feltölteni, aZ SZTE-s társszerzők arányának magasabbnak kell lennie 50\%-nál, a szerzök 2014 óta megjelent publikációinak szerepelnie kell az MTMT-ben és a repozitóriumban. A szabályok egyértelmü célokat szolgálnak: a célfolyóiratok első két kvartilise elősegíti a szerzőknek az idézetek megfelelő számát, ami az egyetem érdeke is, az SZTE-s email cím egyértelmüsíti az affiliációt. Az MTMT és a repozitórium minél alaposabb feltöltöttsége pedig a szerző és az intézmény közös érdeke.

\section{A Read and Publish szerződések beillesztése}

A feltételeket folyamatosan alakitják azok a Read and Publish ${ }^{4}$ publikációs szerződések, amelyeket az egyetem köt az EISZ konzorciumon keresztül. Ezen szerződések, összehasonlítva a korábbi, egyetemünk által kötött szerződésekkel a Gold Open Access kiadókkal, nagyon kedvezményes és nagyszámú publikációs lehetőséget biztositanak, a tiszta Open Access-en felül a hibrid típusú folyóiratokban is ${ }^{5}$.

$4 \quad$ Az olvasáshoz és a nyilt publikáláshoz való jogot egyben kezelő szerződés a kiadókkal

5 Dér Ádám. Könyvtári és konzorciumi kezdeményezések az Open Access átállás elösegitése érdekében. ELTE Egyetemi Könyvtár és Levéltár. Hagyományok és kihivások VI. http://videotorium.hu/hu/recordings/26100 
Már a kezdetekkor alapvető döntést kellett hozzunk. A R\&P szerződéseknek nem feltétlenül kellett volna betagozódniuk a már megkezdett $\mathrm{OA}$ programunkba, müködhettek volna függetlenül, felhasználási feltételek nélkül. Azonban azt tapasztaltuk, hogy az OA adminisztrációs felületek (dashboard) kezelésére ugyanúgy könyvtári munkaerőt kell dedikáljunk, ráadásul rengeteg extra feladatot jelent a szerzők folyamatos tájékoztatása. İgy az tünt a logikus lépésnek, hogy a meglévő struktúrába illesztünk be minden elérhetővé vált új forrást.

2018-ban ezek a típusú szerződések még kuriózumnak számítottak, így a fenti feltételrendszerben egyfajta kivételként szerepeltettük őket, hiszen nem tiszta Open Access kiadókról beszélhettünk, és a rendelkezésre bocsájtott publikációs kereteket igyekezni kellett kitölteni. Időnként a folyóirat szinvonalából is engedtünk, hogy ne menjen veszendöbe a rendelkezésre álló OA kvóta.

A 2019-es évre annyi Read and Publish típusú szerzödést kötött a Szegedi Tudományegyetem az EISZ konzorciumon keresztül, hogy számszerüleg sokkal több Open Access publikálási lehetőséghez jutottunk hozzá, mint amennyit a hagyományos Gold OA vonalon fedezni tudtunk volna. Így az vált kihívássá, hogy a rendelkezésre álló kereteket hasznosan töltsük ki, valamint ne menjen veszendöbe egyetlen APC sem ${ }^{6}$. Az első nagyobb kiadói szerződés, mely azonnal átütő sikerrel indult az SZTE-n, a Springer Nature-rel kötött volt?

Nyilvánvalóvá vált, hogy a korábbi gyakorlat, amikor kivételként, eseti elbírálással kezeltük a Read and Publish típusú publikálási igényeket, nem tartható tovább, hiszen az arányokat tekintve komoly eltolódás történt. Az eredetileg tiszta nyilt hozzáférésü folyóiratokra kidolgozott szabályokat nem akartuk megváltoztatni. Ezeket a roppant drága APC-ket ${ }^{8}$ a tiszta OA folyóiratokban továbbra is csak komoly előzetes szürést követően, az egyetem érdekeit szem előtt tartva akartuk átvállalni a szerzőktöl. A költségkimélöbb R\&P kvótákat viszont maradéktalanul fel szerettük volna használni, minél több szerzőt bevonva ezzel a programba. Emiatt megfogalmaztunk egy második szabályrendszert, ahol engedményeket tettünk az előzőekhez képest. A folyóiratok besorolását tekintve a harmadik kvartilisbe tartozó cimeket is elfogadtuk, az SZTE-s szerzők arányát pedig mindössze 30\%ban határoztuk meg. A választóvonal a két szabályrendszer között a megkötött R\&P szerződések mentén húzódik, szerzőinket gyakran tájékoztatni kell, hiszen könnyedén elveszhetnek az információk tengerében.

Az új "APC állományok" használatba vételekor nagyon hamar kiderült, hogy ezúttal az Open Access szerzői igényeket nem elég passzivan várni. Minden tájékoztatási erőfeszitésünk ellenére sok szerző nem értesült a lehetőségekröl, vagy nem tudja hogyan kell élni velük. Sok esetben, egy cikk elfogadásáról szóló kiadói értesitést

\footnotetext{
$6 \quad$ http://eisz.mtak.hu/index.php/hu/open-access.html

7 http://eisz.mtak.hu/index.php/hu/open-access/286-open-access-megallapodas-aspringer-nature-kiadoval.html

8 Article Processing Charge. A nyilt hozzáférésü folyóiratok esetében a cikk megjelentetéséért felszámított eljárási dij.
} 
kézhez véve azt tapasztaljuk - a késöbb bemutatandó Open Access pályázati rendszerünkben -, hogy a szerző nem pályázott előzetesen. Feltehetőleg nem értesült az OA lehetőségröl, vagy félreértette a kiadói tájékoztatást. Ilyenkor egyenként megkeressük öket, ismertetve a publikálási lehetőségeket és azok feltételeit.

\section{Open Access adminisztrációs rendszer}

A fentiekből kiolvasható, hogy az Open Access munkacsoportunknak nem csak a pályázatot igénylő, egyértelműen más forrást használó, hanem a feltehetőleg hozzánk tartozó igényeket is kezelnie kell. Egy ilyen teljes intézményt átfogó adminisztráció elképzelhetetlen lenne, ha nem állna rendelkezésünkre egy olyan saját fejlesztésü rendszer, amely összeköti az összes résztvevöt, lehetövé téve a pályázatok adminisztrálását, a megszületett cikkek utánkövetését, valamint segítve a pénzügyi és APC adminisztrációt, abból fakadóan, hogy minden adatot egy felületen tárol. A szerző ebben a rendszerben szerkeszti és nyújtja be pályázatát, illetve az esetleges hiánypótlást, majd ezt követően a könyvtáros kollégák elvégzik a döntéselökészitő ellenőrzést, hogy az egyetem felső vezetése meg tudja hozni a döntést. Így amikor egy kiadótól értesítés érkezik egy SZTE affiliációjú OA vagy potenciálian Open Access cikk elfogadásáról, a munkacsoport tagjai már pontosan tudják, hogyadott cikketelutasitani,jóváhagyni kell, esetlega szerzőt kellmegkeresni tájékoztatás céljából. A pályázatokon minden olyan adatot bekérünk a szerzőktől, ami a pályázati feltételek ellenőrzését lehetővé teszi, úgymint a folyóirat adatai, az APC várható összege, a szerzők MTMT, Scopus azonositója illetve ORCID-ja.

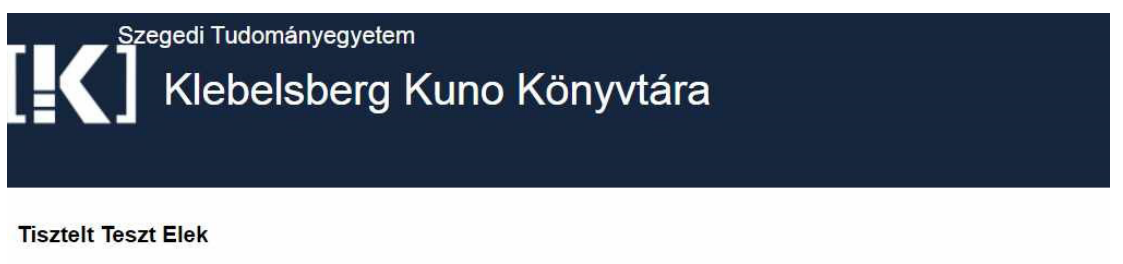

\begin{tabular}{|c|c|c|c|c|c|c|}
\hline \multicolumn{7}{|c|}{ Beadott pályázatának adatail } \\
\hline \multicolumn{4}{|c|}{ Azonosító } & \multicolumn{3}{|c|}{4458} \\
\hline \multicolumn{4}{|c|}{ Kérelmező neve } & & \multicolumn{2}{|c|}{ Teszt Elek } \\
\hline \multicolumn{4}{|c|}{ Kérelmező e-mail címe } & & \multicolumn{2}{|c|}{ szabolcs.hoczopan@ek.szte.hu } \\
\hline \multicolumn{4}{|c|}{ Kar } & & \multicolumn{2}{|c|}{ BBMK - Bartók Béla Müvészeti Kar } \\
\hline \multicolumn{4}{|c|}{ Tanszék } & & \multicolumn{2}{|c|}{ Rézfúvós Tanszék } \\
\hline \multicolumn{4}{|c|}{ OA folyóirat címe } & & \multicolumn{2}{|l|}{ Open Access Journal } \\
\hline \multicolumn{4}{|c|}{ ISSN } & & \multicolumn{2}{|l|}{$0001-5350$} \\
\hline \multicolumn{4}{|c|}{ Kiadó neve } & & \multicolumn{2}{|c|}{ OA Publishing } \\
\hline \multicolumn{4}{|c|}{$\begin{array}{ll}\text { Publikáció cime } \\
\end{array}$} & & \multicolumn{2}{|l|}{ Open Publikáció } \\
\hline \multirow{2}{*}{\multicolumn{4}{|c|}{ APC összege (Publikációs költség, a kiadó által használt devizában.) }} & & \multicolumn{2}{|c|}{2048 EUR } \\
\hline & & & & & \multicolumn{2}{|c|}{$2019 / 11 / 28$} \\
\hline \multicolumn{4}{|c|}{ Leadás időpontja } & & \multicolumn{2}{|c|}{$2019 / 11 / 01$} \\
\hline \multicolumn{7}{|c|}{ Megjegyzés a pályázat elbírálóinak } \\
\hline \multicolumn{7}{|c|}{ Szerzök } \\
\hline Név & Affiláció & $\begin{array}{l}\text { Rendelkezik MTMT } \\
\text { szerzöi azonositóval? }\end{array}$ & \begin{tabular}{|c||} 
MTMT szerzői \\
azonositó
\end{tabular} & $\begin{array}{r}\text { Scopus } \\
\text { Author II }\end{array}$ & ORCID & $\begin{array}{l}\text { Szerzö } \\
\text { tipusa }\end{array}$ \\
\hline $\begin{array}{l}\text { Pröba } \\
\text { Szilärd }\end{array}$ & $\begin{array}{l}\text { Összehasonlitó } \\
\text { Jogi Intézet }\end{array}$ & Igen & 22221111 & & $\begin{array}{l}\text { https://orcid.org/0000- } \\
3333-2222-3333\end{array}$ & Elsö \\
\hline $\begin{array}{l}\text { Társszerzö } \\
\text { Pál }\end{array}$ & $\begin{array}{l}\text { Élelmiszermérnöki } \\
\text { Intézet }\end{array}$ & Igen & 33331111 & & $\begin{array}{l}\text { https://orcid.org/0000- } \\
3333-2222-1111\end{array}$ & $\begin{array}{l}\text { Nincs } \\
\text { megadva }\end{array}$ \\
\hline Teszt Elek & Rézfúvós Tanszék & Igen & 11112222 & & $\begin{array}{l}\text { https://orcid.org/0000- } \\
1111-2222-3333\end{array}$ & Levelezö \\
\hline Név & Affiláció & $\begin{array}{l}\text { Rendelkezik MTMT } \\
\text { szerzői azonosítóval? }\end{array}$ & $\begin{array}{c}\text { MTMT szerzői } \\
\text { azonositó }\end{array}$ & $\begin{array}{l}\text { Scopus } \\
\text { Author ID }\end{array}$ & ORCID & $\begin{array}{l}\text { Szerző } \\
\text { típusa }\end{array}$ \\
\hline
\end{tabular}

1. ábra Szerzöi adatlap 
A beérkező adatok alapján az OA munkacsoport adminisztrátora elkezdi a döntéselőkészitési adatolást. Megjelöli, hogyadott cikk melyik szerződés keretében, melyik szabályzat alapján lesz nyilt hozzáférésü. Leellenőrzi a megadott azonositók alapján, hogy a szerzök cikkei fel vannak-e töltve az MTMT-be és a repozitóriumba. A folyóirat esetében a Scopus és a Web of Science adatok alapján felviszik az adatlapra a kvartilis besorolást, ami a legfontosabb bírálati szempontunk.

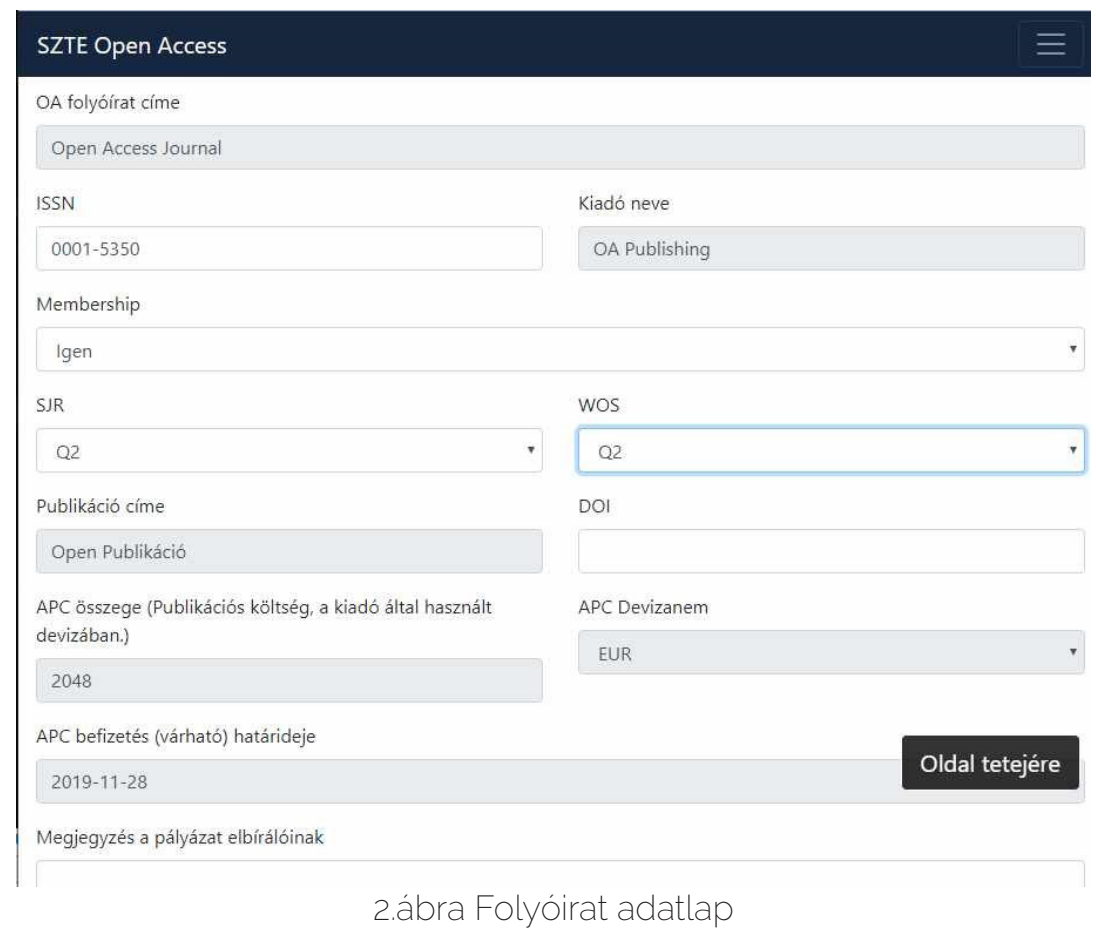

Amennyiben valamely feltételnek a szerző nem felel meg, pályázatát a könyvtári adminisztrátor elutasithatja, ha csak hiánypótlásra van szükség, akkorvisszaküldheti a szerzőnek szerkesztésre, pontosan megjelölve, milyen adatokat kérünk még feltölteni.

Elöfordulhatnak kivételes esetek, például egy tudományterületen kevés nyilt hozzáférésű folyóirat érhető el és azok kvartilis besorolása is az általunk húzott határon billeg. Ebben az esetben az egyetemi felsővezetés automatikusan elutasitaná a pályázatot, azonban az ürlapba be lett épitve egy szabadszöveges mező, ahol az ilyen jellegű kivételes pályázatokat meg tudjuk indokolni, adatokkal alátámasztani.

\section{Döntéstámogatás}

Ha lefutotta pályázatésa cikk megjelent, azOAmunkacsoport munkája nemérvéget: a cikkek utóéletét is folyamatosan figyeljük, idézettségi szempontból. Erre a célra a megjelent cikkek DOI-jait` gyüjtjük az adatbázisban, azokból épitünk egy egyedi 
Muzs Kriszina - Molnár Tamás - Hoczopán Szabolcs: Open Access pályázati rendszer technikai megvalósitása és a szerzők támogatása a Szegedi Tudományegyetemen

entitást az Elsvier Scival tudománymetriai rendszerében. Ennek köszönhetöen folyamatos rálátásunk van az általunk finanszirozott cikkek idézettségére, valamint hatására.

Bár a módszer müködik, a DOl-k kézi gyüjtögetésénél professzionálisabb megoldásra volt szükségünk. Az utánkövetés egyszerüsitésére 2019 júniusától regisztráltuk magunkat a CrossRef FundRef adatbázisában. Az egyetem szerzőit arra kérjük, hogy a FundRef azonositónkat rögzítsék a cikk feltöltésekor. Az így rögzitett azonositó alapján a cikkeink már bármely bibliográfiai adatbázisból lekérdezhetők és elemezhetők lesznek.

Az elemzés és statisztikakészités másik vonulata a pénzügyi utánkövetés Mivel folyamatosan el kell számolnunk az egyetem felé az elköltött APC összegével, ezért természetesen az adatbázisba felvett APC összegek alapján folyamatos kimutatásokat készitünk. Az APC-k folyamatos monitorozásának a könyvelési szükségszerüségen túl, döntéselökészitö jelentősége is van. Amennyiben egy adott kiadónál a számlák összege, gyakorisága kiemelkedő, lehetőség szerint Open Access tagsági (membership) szerződést kötünk velük ${ }^{10}$. Ezzel a lépéssel a későbbi kifizetésekből kedvezményeket tudunk elérni, illetve az APC kifizetés idejét jelentősen redukálni tudjuk, ami a publikációs versenyben nem utolsó szempont.

Külön vonalat képvisel a pénzügyi adminisztrációnkban, hogy azon APC árakat is gyüjtjük, melyek Read and Publish szerződés keretében születő cikkekhez tartoznak. Nyilvánvaló, hogy itt klasszikus értelemben nem tudunk elszámolni a publikációs költségekkel, de egy-egy szerződés későbbi megitélésének szempontjából ez ugyanúgy fontos adat lehet, mint például a "Read" szerződési rész letöltési adatainak gyüjtése és elemzése.

\section{6. Összefoglalás}

A nyilt hozzáférésü publikációkkal kapcsolatosan nyilvánvalóan elképzelhető lenne másfajta ügyintézési metódus is, saját megoldásunkban nem titkoltan a központositott dokumentum beszerzési rendszerünket vettük alapul, ahol a központositott munkafolyamatban az SZTE Klebelsberg Könyvtár hozzáadott értéke az adminisztráció gyorsitásában és az egyetemi szinten is jelentős mértékü megtakaritásokban mutatkozik meg. A központositásnak hála, hasonló eredményeket érhetünk el publikációs vonalon, bár a centralizáció 2019 tavaszán még nem teljesen fejeződött be. Az SZTE beszerzési szabályzatának módositása 2019 nyarára azon kevés APC adminisztrálását is az Egyetemi Könyvtár hatáskörébe utalta, melyek eddig el tudták kerülni a figyelmünket. Így már valóban minden feltétel megteremtődött a hatékony és központositott intézményi Open Access politikához. 